\title{
HUBUNGAN ANTARA DIABETES MELLITUS TIPE II DENGAN DERAJAT OSTEOARTHRITIS LUTUT
}

\author{
Maruf Hari Subroto' ${ }^{1}$, Basuki Supartono ${ }^{2 *}$, Ryan Herardi ${ }^{3}$ \\ ${ }^{1}$ Program Studi Sarjana Kedokteran, Fakultas Kedokteran, Universitas Pembangunan Nasional "Veteran” Jakarta \\ Email : marufhari98@gmail.com \\ ${ }^{2 *}$ Departemen Orthopedi, Fakultas Kedokteran, Universitas Pembangunan Nasional "Veteran" Jakarta \\ Pusat Kajian Stem Cell, Fakultas Kedokteran, Universitas Pembangunan Nasional "Veteran" Jakarta \\ *Email :drbasuki@gmail.com \\ ${ }^{3}$ Departemen Penyakit Dalam, Fakultas Kedokteran, Universitas Pembangunan Nasional "Veteran” Jakarta \\ Email : dr.ryanherardi@gmail.com \\ Jl. RS Fatmawati, Pondok Labu, Jakarta Selatan 12450, Telp. (021) 7656971
}

Masuk: 06-02-2020, revisi: 11-12-2020, diterima untuk diterbitkan: 31-03-2021

\begin{abstract}
ABSTRAK
Osteoarthritis adalah penyakit degeneratif yang disebabkan kerusakan tulang rawan sendi. Osteoarthritis dialami 151,4 juta orang di dunia dan 27,4 juta orang di Asia Tenggara. Osteoarthritis merupakan penyakit yang menjadi beban kesehatan masyarakat dan negara. Prevalensi terjadinya osteoarthritis yaitu satu dari empat orang berusia 50 tahun dan individu berusia lebih dari 65 tahun beresiko mengalami pengapuran sendi lutut. Penelitian osteoarthritis mengamati faktor risiko terjadinya osteoarthritis seperti diabetes mellitus tipe 2. Studi Hispanik menjelaskan prevalensi penderita osteoarthritis dua kali lebih banyak terjadi pada penderita dengan diabetes dibandingkan penderita tanpa diabetes. Pemeriksaan HbAlc direkomendasikan untuk mendiagnosis diabetes, dengan batas nilai 6,5 $\%$. Tujuan penelitian ini adalah untuk mengetahui hubungan antara diabetes mellitus tipe II dengan derajat osteoarthritis lutut. Penelitian ini menggunakan analitik observasional dengan desain penelitian potong lintang dengan jumlah sampel 45 pasien di Poli Orthopedi Rumah Sakit Umum Al - Fauzan tahun 2016 - 2019 dan dianalisa menggunakan uji kai kuadrat. Berdasarkan hasil penelitian, usia terbanyak adalah lansia yaitu 34 orang $(75,6 \%)$, jenis kelamin terbanyak adalah perempuan yaitu 34 orang $(75,6 \%), H b A l c$ terbanyak adalah non diabetes mellitus yaitu 30 orang $(66,7 \%)$, derajat osteoarthritis lutut terbanyak adalah derajat berat (4) yaitu 28 orang $(62,2 \%)$, dan tidak terdapat hubungan yang bermakna antara diabetes mellitus tipe II dengan derajat osteoarthritis lutut dengan nilai $\mathrm{p}$ sebesar 0,828 ( $>$ > 0,05). Penelitian ini menunjukan tidak terdapat hubungan yang bermakna antara diabetes mellitus tipe II dengan derajat osteoarthritis lutut
\end{abstract}

Kata Kunci : Diabetes Mellitus Tipe II; HbAlc; Osteoarthritis Lutut

\begin{abstract}
Osteoarthritis is a degenerative disease that cause damage to joint cartilage damage. Osteoarthritis affects 151,4 million people in the world, including 27,4 million in Southeast Asia. Osteoarthritis is a disease that is a burden on public health and the country. The prevalence of osteoarthritis is one in four people aged 50 years and individuals aged 65 years are more at risk of developing calcification of the knee joint. Risk factors such as type II Diabetes Mellitus are observed in one of osteoarthritis research. A hispanic study explained the prevalence of osteoarthritis patient are twice as much in diabetic patient than non-diabetic patient. A score of $6.5 \%$ of $\mathrm{HbA} 1 \mathrm{c}$ test is required to diagnose diabetes. The goal of this study is to find out the connection of type 2 diabetes mellitus and knee osteoarthritis. This research uses observational analytic with cross sectional research design with a total of 45 patient from Orthopedic clinic of Al - Fauzan General Hospital in 2016 - 2019 and analyzed with chi square test. According to the result, the most group of age is elderly about 34 people (75,6\%), the most group of gender is women about 34 people $(75,6 \%)$, the most group of HbAlc is non-diabetes mellitus group about 30 people $(66,7 \%)$, the most group of osteoarthritis stage is severe de (4) about 28 people $(62,2 \%)$, and there is no connection between type II diabetes mellitus with the stage of knee osteoarthritis with $p$ value of $0,828(p>0.05)$. this research shows no significant correlation between type II diabetes mellitus and the stage of knee osteoarthritis.
\end{abstract}

Keywords : Knee Osteoarthritis; HbA1c; Type II Diabetes Mellitus 


\section{PENDAHULUAN \\ Latar belakang}

Tulang rawan sendi lutut sering mengalami kerusakan sehingga menyebabkan rasa sakit, bengkak, gangguan fungsional, dan kecacatan yang menjadi masalah Kesehatan di masyarakat (Supartono et al, 2018). Kerusakan tulang rawan disebabkan oleh penuaan, trauma, atau faktor lain yang mempengaruhi tulang rawan (Supartono et al, 2018). Osteoarthritis merupakan penyakit degeneratif yang disebabkan kerusakan tulang rawan sendi (Supartono et al, 2018). Osteoarthritis dialami 151,4 juta orang di dunia dan 27,4 juta orang di Asia Tenggara (Supartono et al, 2018). Osteoarthritis merupakan penyakit yang menjadi beban kesehatan masyarakat dan negara (Supartono, 2016). Prevalensi terjadinya osteoarthritis yaitu satu dari empat orang berusia 50 tahun dan individu berusia lebih dari 65 tahun beresiko mengalami pengapuran sendi lutut (Supartono, 2017). Studi Hispanik menjelaskan prevalensi penderita osteoarthritis dua kali lebih banyak pada penderita dengan diabetes dibandingkan penderita tanpa diabetes (Nieves et al, 2013).

Diabetes adalah penyakit metabolik dengan hiperglikemia akibat defisiensi sekresi insulin, kerja insulin, ataupun keduanya (American Diabetes Association, 2014). Penderita diabetes mellitus di dunia meningkat lebih dari dua kali lipat selama tiga dekade terakhir (Chen et al, 2012). Penderita diabetes mellitus di dunia diperkirakan meningkat menjadi 439 juta pada tahun 2030, yang mewakili 7,7 \% populasi orang dewasa berusia $20-79$ tahun di dunia (Chen et al, 2012). Negara dengan jumlah penderita diabetes mellitus terbanyak pada tahun 2030, lima diantaranya berada di Asia yaitu Cina, India, Pakistan, Indonesia, dan Banglades (Chen et al, 2012). Hiperglikemia meningkatkan inflamasi pada sendi dan degradasi tulang rawan melalui stres oksidatif, induksi mediator inflamasi, serta produk akhir glikasi (Louati et al, 2015). Produk akhir glikasi berperan dalam degenerasi tulang rawan pada osteoarthritis (Burner \& Rosenthal, 2009). Produk akhir glikasi yang meningkat mengurangi kemampuan pemeliharaan dan perbaikan tulang rawan yang berperan dalam terjadinya osteoarthritis. Tujuan penelitian ini adalah untuk mengetahui hubungan yang bermakna antara diabetes mellitus tipe II dengan derajat osteoarthritis lutut.

\section{METODE PENELITIAN}

\section{Desain penelitian}

Jenis penelitian yang digunakan adalah analitik observasional dengan desain penelitian potong lintang. Penelitian dilakukan untuk mengetahui hubungan yang bermakna antara diabetes mellitus tipe II dengan derajat osteoarthritis lutut pada pasien di Poli Orthopedi Rumah Sakit Umum AlFauzan tahun 2016 - 2019.

\section{Populasi dan Sampel}

Populasi dalam penelitian ini adalah pasien di Rumah Sakit Umum Al-Fauzan tahun 2016 - 2019. Sampel dalam penelitian ini adalah pasien osteoarthritis lutut di Poli Orthopedi Rumah Sakit Umum Al-Fauzan tahun 2016 - 2019 yang memenuhi kriteria inklusi dan eksklusi. Kriteria inklusi penelitian ini adalah pasien osteoarthritis lutut, pasien osteoarthritis lutut derajat 1 sampai 4 Kellgren Lawrence, dan pasien osteoarthritis lutut yang mengalami diabetes mellitus tipe II, prediabetes, dan non diabetes mellitus. Kriteria eksklusi penelitian ini adalah pasien osteoarthritis selain osteoarthritis lutut, pasien osteoarthritis lutut yang mengalami obesitas menurut kriteria $W H O$, gangguan postur, dan aktifitas fisik berat.

\section{Pengambilan sampel}

Pengambilan sampel pada penelitian ini menggunakan sampel acak sederhana 


\section{Pengumpulan data}

Data yang digunakan adalah data sekunder rekam medik pasien di Rumah Sakit Umum Al Fauzan tahun 2016 - 2019 yang terkait variabel.

\section{Analisis data}

Analisis data menggunakan uji kai kuadrat. Apabila tidak memenuhi syarat uji kai kuadrat maka digunakan uji alternatif kolmogorov smirnov. Jika nilai $\mathrm{p}<0,05$ artinya terdapat hubungan yang bermakna antara variabel independen dengan variabel dependen dan jika nilai $p>0,05$ artinya tidak terdapat hubungan yang bermakna antara variabel independen dengan variabel dependen.

\section{HASIL DAN PEMBAHASAN}

\section{Karakteristik responden}

Karakteristik responden digunakan untuk mengetahui gambaran usia, jenis kelamin, derajat osteoarthritis lutut, dan HbAlc pasien. Distribusi karakteristik responden berdasarkan usia pasien di Poli Orthopedi Rumah Sakit Umum Al - Fauzan tahun 2016 - 2019 sebagian besar adalah lansia berusia lebih dari 60 tahun sebanyak 34 orang $(75,6 \%)$ pasien. Berdasarkan jenis kelamin pasien di Poli Orthopedi Rumah Sakit Umum Al - Fauzan tahun 2016 - 2019 sebagian besar adalah perempuan sebanyak 34 orang (75,6\%) pasien. Berdasarkan HbAlc pasien di Rumah Sakit Umum $\mathrm{Al}$ - Fauzan tahun 2016 - 2019 sebagian besar adalah non diabetes mellitus sebanyak 30 orang $(66,7 \%)$ pasien. Berdasarkan derajat osteoarthritis lutut pasien di Poli Orthopedi Rumah Sakit Umum Al - Fauzan tahun 2016 - 2019 sebagian besar adalah derajat berat (4) sebanyak 28 orang $(62,2 \%)$ pasien. Distribusi karakteristik responden dapat dilihat pada tabel 1.

Tabel 1. Distribusi Karakteristik Responden di Poli Orthopedi Rumah Sakit Umum Al - Fauzan tahun 2016 - 2019

Sumber Tabel : Data Sekunder, 2016 - 2019

\begin{tabular}{ccc}
\hline & Frekuensi (n) & Persentase (\%) \\
\hline Usia & 11 & 24,4 \\
Usia Pertengahan (45 - 59) & 34 & 75,6 \\
Lansia (>60) & 11 & \\
Jenis Kelamin & 34 & 24,4 \\
Laki - Laki & & \\
Perempuan & 30 & 66,7 \\
\hline HbAlc & 15 & 33,3 \\
\hline Non Diabetes Mellitus & & \\
Diabetes Mellitus & 17 & 37,8 \\
\hline Derajat Osteoarthritis Lutut & 28 & 62,2 \\
Ringan (1 - 3) & &
\end{tabular}

\section{Hubungan Antara Diabetes Mellitus Tipe II Dengan Derajat Osteoarthritis Lutut}

Analisis bivariat yang digunakan dalam penelitian ini adalah uji kai kuadrat. Hasil analisis bivariat untuk mengetahui hubungan antara diabetes mellitus tipe II dengan derajat osteoarthritis lutut didapatkan nilai $\mathrm{p} 0,828$ ( $\mathrm{p}>0,05)$ yang menjelaskan tidak terdapat hubungan yang bermakna antara diabetes mellitus tipe II dengan derajat osteoarthritis lutut. Analisis bivariat dapat dilihat pada tabel 2. 
Tabel 2. Hubungan Antara Diabetes Mellitus Tipe II Dengan Derajat Osteoarthritis Lutut Sumber : Data Sekunder, 2016 - 2019

\begin{tabular}{|c|c|c|c|c|c|c|c|c|}
\hline \multirow{3}{*}{$H b A l c$} & \multicolumn{4}{|c|}{ Derajat Osteoarthritis Lutut } & \multirow{2}{*}{\multicolumn{2}{|c|}{ Total }} & \multirow{3}{*}{ OR } & \multirow{3}{*}{ Nilai P } \\
\hline & \multicolumn{2}{|c|}{ Ringan $(1-3)$} & \multicolumn{2}{|c|}{ Berat (4) } & & & & \\
\hline & $\mathrm{N}$ & $(\%)$ & $\mathrm{N}$ & $(\%)$ & $\mathrm{N}$ & $(\%)$ & & \\
\hline $\begin{array}{c}\text { Non } \\
\text { Diabetes } \\
\text { Mellitus }\end{array}$ & 11 & 24,4 & 19 & 42,2 & 30 & 66,7 & \multirow{3}{*}{0,868} & \multirow{3}{*}{0,828} \\
\hline $\begin{array}{l}\text { Diabetes } \\
\text { Mellitus }\end{array}$ & 6 & 13,3 & 9 & 20,0 & 15 & 33,3 & & \\
\hline Total & 17 & 37,8 & 28 & 62,2 & 45 & 100 & & \\
\hline
\end{tabular}

\section{Pembahasan}

Berdasarkan hasil penelitian, distribusi responden berdasarkan usia menunjukkan bahwa sebagian besar responden adalah lansia berusia lebih dari 60 tahun sebanyak 34 orang $(75,6 \%)$ pasien. Hasil ini sesuai dengan penelitian Supartono (Supartono, 2017) yang menyatakan bahwa seseorang yang berusia lebih dari 65 tahun berisiko tinggi mengalami pengapuran sendi lutut. Proses penuaan menyebabkan pembengkakan jaringan dan pelepasan zat yang bersifat racun terhadap tulang rawan yang mengakibatkan kerusakan progresif (Supartono, 2017).

Distribusi responden berdasarkan jenis kelamin menunjukkan bahwa sebagian besar responden adalah perempuan sebanyak 34 orang $(75,6 \%)$ pasien. Hasil ini sesuai dengan penelitian Hunter \& Zeinstra (Hunter \& Zeinstra, 2019) yang menyatakan bahwa osteoarthritis lutut lebih banyak terjadi pada wanita dibandingkan pria. Johnson (Johnson \& Hunter, 2014) menyatakan bahwa wanita lebih berisiko mengalami osteoarthritis lutut, terutama setelah menopause. Meningkatnya prevalensi osteoarthritis saat menopause menjelaskan hipotesis mengenai peran estrogen dalam osteoarthritis (Johnson \& Hunter, 2014)

Distribusi responden berdasarkan derajat osteoarthritis lutut menunjukkan bahwa sebagian besar responden mengalami osteoarthritis lutut derajat berat (4) sebanyak 28 orang $(62,2 \%)$ pasien. Pada penelitian Ali (Ali, 2017), pasien yang terdiagnosis osteoarthritis lutut derajat 3 dan 4 merupakan kelompok terbanyak.

Berdasarkan hasil penelitian menunjukkan bahwa pasien non diabetes mellitus dengan proporsi terbesar sebanyak 19 orang (42,2\%) pasien mengalami osteoarthritis lutut derajat berat, kemudian pasien diabetes mellitus dengan proporsi terbesar sebanyak 9 orang $(20,0 \%)$ pasien mengalami osteoarthritis lutut derajat berat. Berdasarkan hasil analisis bivariat menggunakan uji kai kuadrat didapatkan nilai $\mathrm{p} 0,828(\mathrm{p}<0,05)$ yang menunjukkan tidak terdapat hubungan yang bermakna antara diabetes mellitus tipe II dengan derajat osteoarthritis lutut.

Penelitian ini sesuai dengan penelitian Shin (Shin, 2014), yang menjelaskan bahwa tidak terdapat hubungan yang bermakna antara diabetes mellitus tipe 2 dengan osteoarthritis. Penelitian ini tidak berhubungan karena pada penelitian ini tidak menyertakan pasien osteoarthritis lutut yang mengalami obesitas menurut $W H O$ pada penelitian. Shin (2014) menyatakan obesitas sebagai faktor resiko terjadinya osteoarthritis lutut. Obesitas menyebabkan stres mekanik dan menimbulkan kerusakan tulang rawan sendi (Supartono, 2017). Penelitian ini sesuai dengan penelitian Sturmer (Sturmer, 2001) yang menjelaskan bahwa tidak terdapat hubungan antara diabetes mellitus tipe II dengan osteoarthritis. Sturmer (2001) menjelaskan obesitas sebagai faktor resiko osteoarthritis. 
Penelitian ini tidak sesuai dengan penelitian Louati (Louati et al, 2015), yang menjelaskan bahwa osteoarthritis lebih banyak terjadi pada pasien dengan diabetes mellitus. Hiperglikemia meningkatkan peradangan sendi dan degradasi tulang rawan melalui stres oksidatif dan induksi mediator inflamasi oleh produk akhir glikasi (Louati et al, 2015). Penelitian ini tidak sesuai dengan penelitian Piva (Piva et al, 2015), yang menjelaskan bahwa seseorang dengan diabetes mellitus tipe II lebih berisiko mengalami osteoarthritis. Hiperglikemia menyebabkan kerusakan tulang rawan melalui mekanisme produk akhir glikasi (Piva et al,2015). Penelitian ini tidak sesuai karena tidak menyertakan produk akhir glikasi dalam penelitian.

\section{KESIMPULAN DAN SARAN}

Kesimpulan penelitian ini adalah tidak terdapat hubungan yang bermakna antara diabetes mellitus tipe II dengan derajat osteoarthritis lutut pada pasien di Poli Orthopedi Rumah Sakit Umum Al Fauzan tahun 2016 - 2019 dengan nilai p pada uji kai kuadrat sebesar 0,828 (p > 0,05)

\section{Ucapan Terima Kasih}

Terimakasih kepada Direktur Rumah Sakit Umum Al - Fauzan dr.Prita Kusumaningsih, Sp.OG yang telah memberikan izin kepada peneliti untuk melakukan penelitian, Ibu Nia, Ibu Latifah, dan seluruh staf Rumah Sakit Umum Al Fauzan yang terlibat dalam kelancaran penelitian ini.

\section{REFERENSI}

Ali, SJ. (2017). Hubungan Antara Derajat Radiologi Menurut Kellgren Dan Lawrence Dengan Tingkat Nyeri Pada Pasien Osteoarthritis Genu Di RS.Universitas Hassanuddin. Skripsi Universitas Hasanuddin

American Diabetes Association. (2014). Diagnosis and Classification of Diabetes Mellitus. Diabetes Care, 37(1), 81 - 90.

Burner T.W, Rosenthal A.K. (2009). Diabetes and rheumatic diseases. Curr Opin Rheumatol. 21(1), 50-4. doi: 10.1097/BOR.0b013e32831bc0c4

Chen, L. Magliano, DJ. \& Zimmet, PZ. (2012). The worldwide epidemiology of type 2 diabetes mellitus - present and future perspectives. Nature Reviews Endocrinology, 8(4), 228 236.

Hunter, DJ. \& Zeinstra, SB. (2019). Osteoarthritis. The Lancet, 393(10182), 1745 - 1759.

Johnson, VL. \& Hunter, DJ. (2014). The epidemiology of osteoarthritis. Best Practice \& Research Clinical Rheumatology, 28(1), 5 - 15.

Louati, K. Vidal, C. Berenbaum, F. \& Sellam, J. (2015). Association between diabetes mellitus and osteoarthritis : systematic literature review and meta analysis. RMD Open, 1(1), 1 10.

Nieves Plaza, M. Castro Santana, LE. et al. (2013). Association of Hand or Knee Osteoarthritis With Diabetes Mellitus in a Population of Hispanics From Puerto Rico. JCR : Journal of Clinical Rheumatology, 19(1), $1-6$.

Piva, SR. Susko, AM. Khoja, SS. et al. (2015). Links Between Osteoarthritis and Diabetes : Implications for Management from a Physical Activity Perspective. Clinics in Geriatric Medicine, 31(1), $67-87$.

Sastroasmoro, S. \& Ismael, S. (2014). Dasar - Dasar Metodologi Penelitian Klinis. Sagung Seto, Jakarta.

Shin, D. (2014). Association Between Metabolic Syndrome, Radiographic Knee Osteoarthritis, and Intensity of Knee Pain : Results of a National Survey. The Journal Of Clinical Endocrinology \& Metabolism, 99(9), 3177 - 3183. 
Sturmer, T. Brenner, H. Brenner, RE. \& Gunther, KP. (2001). Non - Insulin Dependent Diabetes Mellitus (NIDDM) and Patterns of Osteoarthritis. Scandinavian Journal of Rheumatology, $30(3), 169-171$.

Supartono, B. (2017). Bunga Rampai Kedokteran Olahraga. Pusat Kajian Stem Cell Fakultas Kedokteran Universitas Pembangunan Nasional "Veteran" Jakarta, Jakarta.

Supartono, B. Amalia, R. Satya, I. \& Wiyono, S. (2018). Relation Between Osteoarthritis Grading Scale with Cartilage Ultrasonographic in Knee Osteoarthritis Patient at RSU Al Fauzan Period of 2016 - 2017. Journal of Medical - Clinical Research \& Reviews, 2(6), 1 - 4.

Supartono, B. Ismail, EH. Boediono, A. Shirakawa, T. et al. (2018). Hyaline Cartilage Regeneration on Osteochondral defects by Intraarticular Injection of Human Peripheral Blood $\mathrm{CD}^{34+}$ Cells, Hyaluronic Acid and Growth Factor in a Rat Model. Biomedical Journal of Scientific \& Technical Research, 7(1), 5617 - 5626. 